\title{
Dorota Pauluk, Ukryte programy uniwersyteckiej edukacji i ich rezultaty. Doświadczenia studentów pedagogiki, Wydawnictwo Uniwersytetu Jagiellońskiego, Kraków 2016, ss. 344
}

Dorota Pauluk, doktor nauk humanistycznych w zakresie pedagogiki, w specjalności pedagogika społeczna, zatrudniona w Instytucie Pedagogiki Wydziału Filozoficznego Uniwersytetu Jagiellońskiego, jest autorką interesującej monografii Ukryte programy uniwersyteckiej edukacji i ich rezultaty. Doświadczenia studentów pedagogiki, której recenzentem wydawniczym została znana pedagog Maria Czerepaniak-Walczak. Wśród innych prac Autorki omawianej rozprawy można odnaleźć również monografię pt. Modele ról kobiety w podręcznikach do wychowania seksualnego (2005) opartą na rozprawie doktorskiej z 2002 roku oraz wiele artykułów poświęconych m.in. relacjom student-nauczyciel akademicki, refleksjom nad akademicką edukacją pedagogów, a także problematyce feminologicznej. Pauluk jest też redaktorką naukową zbiorowej monografii Student na współczesnym uniwersytecie - ideały i codzienność (2010).

Autorka w najnowszej publikacji zaprezentowała swe badania teoretyczne i empiryczne nad ukrytymi programami uniwersytetu, czyli diagnozą nieoficjalnych, a czasem niepożądanych rezultatów edukacji akademickiej. Sam termin „ukryty program” edukacji, występujący w naukach społecznych od lat sześćdziesiątych dwudziestego wieku, jest powiązany z nurtem badań pedagogiki krytycznej, wyrosłym na gruncie amerykańskim, a rozpowszechnionym w Polsce m.in. przez Tomasza Szkudlarka. Pedagogika ta nawiązuje zarówno do osiągnięć frankfurckiej szkoły filozoficznej, z uwzględnieniem badań psychologii społecznej, jak i do

1 Paweł Zieliński, Instytut Pedagogiki, Wydział Pedagogiczny, Akademia im. Jana Długosza w Częstochowie, Polska, pawelalek.zielinski@gmail.com. 
(niektórych) koncepcji feministycznych i postmodernistycznych (por. Szkudlarek, 2004, s. 364 i n.; por. też: Szkudlarek, 1993). Pedagogika krytyczna wnika w rozmaite ideologie edukacyjne, za którymi stoją zazwyczaj czyjeś potrzeby, interesy i racje. Stara się wyjść poza myślenie ideologiczne i w sposób pogłębiony wyjaśnić konflikty i nierówności społeczne (por. McLaren, 2015, s. 223). Ma też swoisty etos, o którym następująco pisał Peter McLaren:

Tym, co łączy pedagogów krytycznych, są raczej cele: dać słabym siłę, zaradzić nierównościom i niesprawiedliwości (McLaren, 2015, s. 364-365).

W uzasadnieniu wyboru tematu Autorka omawianej dysertacji wskazuje na ograniczanie badań nad ukrytym programem zazwyczaj do szkół lokujących się poniżej szkolnictwa akademickiego, a przecież dotyczy on całej instytucjonalnej oświaty. Współczesne szkolnictwo wyższe w Polsce dostosowuje się do systemu bolońskiego, w czym również może tkwić możliwość oddziaływania ukrytych programów, przemoc strukturalna i symboliczna. Podobnie jak w innych typach szkolnictwa, także w szkołach wyższych istnieje „drugie życie” - kierujące się celami odmiennymi od zaplanowanych do realizacji w oficjalnych programach. Zatem Autorka w omawianej pracy zmierza do rozpoznania:

[...] ukrytego programu poprzez niezamierzone lub nie do końca zamierzone rezultaty uniwersyteckiej edukacji, zarówno te negatywne, jak i pozytywne, a doświadczane przez studentów pedagogiki jednego z polskich uniwersytetów (s. 13).

Chodzi tu zwłaszcza o skupienie się na problematyce inercyjnych i jednocześnie kazualnych aspektów edukacji akademickiej, jej niezamierzonych skutków.

Dzieło składa się z Wprowadzenia, ośmiu rozdziałów, zakończenia zatytułowanego Uogólnienia i wnioski, bibliografii, a także aneksu. Prawie każdy rozdział zawiera cztery podrozdziały, za wyjątkiem czwartego, który zawiera ich trzy, i ósmego, zawierającego pięć podrozdziałów. Ponadto wiele podrozdziałów składa się z dalszych „podpodrozdziałów”, uszczegółowiających i zarazem porządkujących wybrane treści. W drugiej części pracy, a zatem tej odnoszącej się do prezentacji i omawiania wyników badań empirycznych, czyli począwszy od rozdziału piątego, Autorka konsekwentnie zamieszcza w każdym rozdziale Podsumowanie.

Pierwszy rozdział pracy skupia się na wyjaśnieniu pojęcia „ukryty program”, jego ujęciach w oparciu o różne stanowiska teoretyczne, a także zawiera analizę 
obecności zagadnienia w polskiej literaturze naukowej. Drugi rozdział dotyczy obrazu studenta uzyskanego z perspektywy przeobrażającego się modelu uniwersytetu, teorii rozwoju studenta w powiązaniu z przemianami lat sześćdziesiątych dwudziestego wieku, a także w okresie jego życia przed uzyskaniem pełnej dorosłości. Ponadto rozdział ten zawiera omówienie specyfiki współczesnego pokolenia studentów. Kolejny rozdział koncentruje się na warunkach stymulujących i utrudniających rozwój studenta w środowisku akademickim. Autorka jeden z podrozdziałów poświęciła również zagadnieniu specyfiki studiów pedagogicznych i ich studentów w kontekście przemian szkolnictwa wyższego.

Wymienione dotychczas rozdziały części teoretycznej pracy porządkują w oparciu o literaturę obcą i polską informacje, definicje i koncepcje dotyczące ukrytego programu, zbierając je w jednym miejscu, co bez wątpienia wymagało od Autorki sporego wysiłku intelektualnego i czasu. Ponieważ mnogość stanowisk nie rozstrzyga jednoznacznie przedmiotu badań, Autorka wyodrębniła jego „konstytutywne” właściwości, dostrzegając przy tym procesualność i złożoność badanej kategorii, jej zależność i uwikłanie w proces nie tylko edukacyjny, ale i inne procesy, np.: kulturowe, polityczne i ekonomiczne. Badaczka wiąże siłę i skutki oddziaływania ukrytego programu na studentów z ich dojrzałością rozwojową i moralną, odwołując się zarówno do teorii Erika Eriksona, jak i Lawrence’a Kohlberga. Zdaje się też doceniać rolę własnego wysiłku jednostki oraz środowiska, w tym akademickiego, w procesie dorastania studentów. To ostatnie, czyli uczelnia akademicka - jej zdaniem - może odgrywać zarówno pozytywną, jak i negatywną rolę w tym procesie. Zwłaszcza jej model, bardziej technologiczny niż humanistyczny, może utrudnić ten proces, zamiast go wspierać. Zatem Autorka traktuje niezamierzone rezultaty edukacji akademickiej jako orzeczenie o istnieniu i oddziaływaniu ukrytych programów akademickich. Główny problem badawczy wyartykułowany w rozdziale czwartym brzmi:

Jakie są ukryte programy uniwersyteckiej edukacji i ich rezultaty w doświadczeniach studentów pedagogiki? (s. 137)

Problemy szczegółowe dotyczą skutków oddziaływania ukrytych programów na studentów w ich procesie uczenia się życia, roli eksperta, roli studenta, ponadto strategii radzenia sobie na studiach przez studentów pedagogiki, warstw ukrytych programów (czyli tych ich części, które ujawniają się w toku nie bezpośredniej obserwacji, lecz pogłębionych analiz) w treści doświadczeń studentów, charakteru oddziaływania tych programów i ich poziomów „ukrytości” i „intencjonalności” (s. 138). W celu odpowiedzi na postawione pytania badaczka odwołała się do 
analizy treści swobodnych wypowiedzi studentów, które podległy kategoryzacji za pomocą tzw. klucza kategoryzacyjnego, specjalnego narzędzia, które stworzyła na potrzeby badań (wykorzystana wersja klucza kategoryzacyjnego została zaprezentowana w tabeli na s. 151-152). Uzyskany materiał źródłowy został ujęty w system kategorii i podkategorii, których dotyczą niezaplanowane rezultaty studiów, powiązanych ze sferami życia studentów pedagogiki, przedstawionych w kolejności jako: rozwój osobowy, czyli uczenie się życia, a także uczenie się roli eksperta w wybranej dziedzinie, ponadto - roli studenta oraz funkcjonowania na uniwersytecie jako instytucji społecznej. Badaczka dążyła również do uchwycenia jak największej liczby elementów ukrytego programu w postaci „płynnych, zmieniających się w czasie jakości” (s. 153). Same badania przeprowadzono w dwóch turach. Pierwsze, zrealizowane na przełomie 2011 i 2012 roku, objęło 113 studentów pedagogiki studiów stacjonarnych pierwszego i drugiego stopnia, drugie - z początku 2014 roku - objęło 206 podobnie skategoryzowanych studentów, łącznie przebadano 319 studentów, w większości kobiet. Każdy z nich napisał esej na temat Czego uczq studia? (s. 150). Należy docenić starania badaczki związane z odwołaniem się do badań niereaktywnych, służących poznaniu życia społecznego bez bezpośredniego oddziaływania na nie. Ponadto zastosowanie metody analizy treści, jednej z kilku wymienianych we wspomnianym typie badań społecznych, umożliwia rejestrowanie ludzkich przekazów przy zaoszczędzeniu czasu i środków materialnych przez badacza. Metoda ma i inne zalety, ale też wady, jak np. te związane z trafnością i rzetelnością badań (por. Babbie, 2004, s. 340-353). Z uwagi na wspomniane wady metody sensowne wydawałoby się jednak odwołanie również do innych metod badań w celu podniesienia ich rzetelności.

Co wynika z badań Autorki w oparciu o analizę treści wypowiedzi studentów pedagogiki? Rozdział piąty koncentruje się na rozwoju osobowym studenta jako rezultacie ukrytych programów edukacji akademickiej. Analizy wskazują przede wszystkim na pozytywne niezamierzone skutki w tym rozwoju. Należy do nich osiąganie dojrzałości psychicznej i społecznej przez rozwijanie takich cech osobowości i umiejętności w stronę większej dojrzałości, jak: dostrzeganie własnych mocnych stron, budowanie pozytywnego obrazu siebie, radzenie sobie z utrudnieniami i przeciwnościami codziennego życia oraz stresem. Jest to wiedza wykraczająca poza określanie jej mianem akademickiej. Studia kształtują samoświadomość, rozwijają zainteresowania, umożliwiają przekraczanie swojego dotychczasowego „ja”. Zdaniem studentów te wartości są wynikiem przede wszystkim ich własnej pracy oraz czynników leżących poza edukacją formalną, co Autorka wiąże ze specyfiką rozwojową charakterystyczną dla określonego wieku studentów, czyli ich krytycznego stosunku do wszelkich autorytetów (s. 177-179). Sygnalizowałoby 
to przebywanie studentów studiów stacjonarnych i niestacjonarnych na poziomie postkonwencjonalnym rozwoju moralnego, jednak może to wzbudzać zastrzeżenia związane z wynikami wcześniejszych badań, np. Wojciecha Pasterniaka. Ponadto Autorka powątpiewa w niezależność studentów w pozyskaniu wzmiankowanych kompetencji od oddziaływania jawnego programu studiów, zwłaszcza że odwoływali się oni do pewnych teorii naukowych przy uzasadnianiu własnego punktu widzenia. Chodziło tu przede wszystkim o rozwijanie „humanistycznego światopoglądu” studentów. Wpływa na to również - zdaniem badaczki - sama specyfika obranego kierunku studiowania, a pozytywne cechy rozwoju własnej osobowości wskazywane przez studentów ponadto mogą mieć charakter zgoła „życzeniowy” (s. 179-180).

Rozdział szósty dotyczy uczenia się roli eksperta w wyniku oddziaływania ukrytych programów uniwersyteckiej edukacji pedagogów. Już takie sformułowanie tytułu rozdziału wzbudza zdziwienie, gdyż sugeruje, że osiągnięcia w zakresie bycia ekspertem pedagogiki są powiązane z oddziaływaniami pozaformalnymi edukacji akademickiej. Być może rozstrzygnięciem jest odpowiedź, o jakie rodzaje i poziomy znawstwa tu chodzi. Odpowiedź badaczki sugeruje, że chodzi tu o obraną dyscyplinę studiów, (roz)poznawaną przez studentów w sposób formalny i pozaformalny. Studenci dostrzegli rozbieżności między ofertą akademickiego kształcenia a realiami rynku pracy i jego zapotrzebowaniem. Szukając wiedzy na temat obranej dyscypliny z innych źródeł, studenci dostrzegli jej niski status na tle innych dyscyplin, jej słabość prestiżową oraz brak wyrazistych perspektyw zawodowych. Umocnieniu takiego wizerunku pedagogiki sprzyjają niewiele wymagający wykładowcy oraz słabi, przypadkowi studenci. W związku z tym studenci ocenili przydatność studiów według kryterium ich „praktyczności”, zostały one zdeprecjonowane jako przygotowujące do bezrobocia i zmuszające do uzupełnienia wykształcenia. To „rozczarowanie” studiami, które nie potrafią umiejętnie przygotować studentów jako ekspertów pedagogiki, ma sprzyjać również, zdaniem Autorki, szukaniu dróg „obejścia systemu”. Jednak to pozyskanie nowej, „odidealizowanej” i „realistycznej” wizji stanu rzeczy - paradoksalnie - może być silną stroną studiowania pedagogiki i sprzyjać już właściwej ocenie w zakresie dalszych planów życiowych i zawodowych, ponadto uzyskane kompetencje mogą okazać się w tym bardzo przydatne. Zatem studia uczą zaradności, elastyczności, umiejętności w zakresie dokształcania się, radzenia sobie z problemami, które trudno przewidzieć (s. 206-209).

Rozdział siódmy dotyczy uczenia się roli studenta w zależności od oddziaływania ukrytych programów uniwersyteckiej edukacji. Autorka zauważa, że na początku swej kariery akademickiej studenci przeżywają szok związany ze zmianą 
środowiska kształcenia i potrzebą opanowania nowych kompetencji w zakresie uczenia się (s. 251). Oznacza to również, że szkoły niższego stopnia, zwłaszcza średnie, w małym stopniu uczą samodzielności w tym zakresie. W tym kontekście szkoła wyższa oddziałuje w ten sposób, że z jednej strony podporządkowuje studenta swym formalnym i nieformalnym wymogom, ucząc uległości i konformizmu, a z drugiej hartuje, wzmacnia go, uczy wiary w siebie i radzenia sobie z problemami. Studenci doceniają atmosferę stwarzaną przez nauczycieli na zajęciach, jednak krytykują powszechnie stosowane przez nich metody podające, negatywnie oceniając kompetencje dydaktyczne swych nauczycieli akademickich. Studencki stosunek do wiedzy „teoretycznej” jest zgoła odmienny od stosunku ich nauczycieli. Wypracowywane strategie uczenia się, jak twierdzi Autorka, można potraktować jako pozytywne, gdy są motywowane wewnętrzną potrzebą wiedzy i rozwijania się, gdy studenci uczą się wspólnie z innymi i do tego poza murami uczelni, w ten sposób wyrównując jej braki i niedociągnięcia. Strategie negatywne nastawione są na uzyskanie wymiernej korzyści w krótkim czasie i nie pozwalają na długie zachowanie wiedzy. Zatem studenci postrzegają edukację sformalizowaną (jako taką) negatywnie, a jej wpływ na swoje życie pozytywnie, gdyż pozwala ostatecznie rozwinąć pożądane cechy osobowości, zapewnia rozwój intelektualny, społeczny, a także wzmacnia własne „ja”. Dzieje się to zwłaszcza pod wpływem studenckiej grupy rówieśniczej, gdzie można, ich zdaniem, odnaleźć rzeczywiste wsparcie i pomoc. Strategia „byle nie oblać” nie rozwija rywalizacji, a wręcz stymuluje pracę grupową, która służy zarówno rozwojowi kompetencji społecznych, jak i próżniactwu społecznemu, jak to ujęła Autorka (s. 251-252).

Rozdział ósmy dotyczy strategii radzenia sobie na studiach jako reakcji zwrotnej studentów na ukryte programy edukacji uniwersyteckiej. Po doświadczeniu wspomnianego początkowego szoku w związku z odmiennością procesu edukacji na wyższym szczeblu z czasem studenci wypracowują pewne strategie radzenia sobie z napotkanymi trudnościami w procesie studiowania, również przez opanowanie wiedzy nieformalnej. Pozwala ona - zdaniem Autorki - obniżyć ich poczucie frustracji z powodu dostrzeżenia luk powiązanych z zajęciami praktycznymi, wiedzą specjalistyczną i tą dotyczącą życia, w tym praktyki uprawiania zawodu, zatem studenci dostrzegają i reagują na rozbieżności między wiedzą akademicką a wiedzą „życiową”. Samodzielność, którą rozwijają, jest pozytywnym skutkiem radzenia sobie z trudnościami, które ma jednak również negatywne następstwa zaniedbywanie samego studiowania, „kombinowanie”. Jego skala może przerastać wyobrażenia nauczycieli akademickich, a „metody” nie zostały przecież w pełni ujawnione przez studentów. Można wydzielić „miękkie” strategie przetrwania na 
studiach, ale też „twarde”, związane z łamaniem zasad obyczaju, etyki i prawa. Studia traktowane są instrumentalnie, a brak czy niewłaściwa reakcja ze strony nauczycieli i władz akademickich oraz zły przykład idący od innych studentów pogłębiają patologię. Wbrew założeniom wzorcowych efektów kształcenia dla pedagogiki, powiązanych z profesjonalizmem i etyką zachowania absolwenta, studenci bagatelizują i usprawiedliwiają swe nieetyczne zachowania i stosowane strategie, szukając winy poza sobą, obarczając nią uczelnię czy nauczycieli akademickich. Ponadto ich tłumaczenia zawierają argumenty o powszechności zjawiska, odwoływaniu się do zapewnienia sobie dobrostanu, a nawet gloryfikacji tych nieetycznych zachowań jako „sprytnych” i pożądanych strategii we współczesnym życiu - najwyraźniej arenie walki o przetrwanie i uzyskanie wyższego statusu materialnego i społecznego (s. 257-271). W ten sposób obnażony zostaje mit posłannictwa uniwersytetu, a także potwierdzają się diagnozy wynikłe z badań wspomnianego W. Pasterniaka. W pracy O pedagogice wyższych stanów świadomości (2003) uczony ten przedstawił wyniki własnych badań dotyczących samopoznania studentów pedagogiki, przeprowadzonych w latach 1997-2002, którymi objął 237 studentów studiów stacjonarnych i niestacjonarnych. Z uzyskanych wywiadów po ich opracowaniu wyłonił się obraz studenta pedagogiki, który idealizuje własną osobę, ma trudności z ujęciem własnych antywartości, wad i konfliktów, czyli studenta jako bardzo niedojrzałej osoby.

W Uogólnieniach $i$ wnioskach Autorka zwraca uwagę na istnienie nie jednego, ale wielu ukrytych programów, wytwarzanych zarówno przez nauczycieli akademickich, jak i studentów. Nieformalna wiedza, zdobywana i stale rozbudowywana przez studentów, ma służyć im w poprawie funkcjonowania w rzeczywistości akademickiej. Wśród niezamierzonych rezultatów akademickiej edukacji znalazły się te powiązane ze zniekształcaniem przez nauczycieli akademickich oficjalnych programów, jak np. sprzeczne przekazy i stałe elementy konstytutywne dla akademickiego procesu nauczania, ponadto bardziej rozmyte efekty dotyczące specyfiki danej szkoły, jej tradycji i struktury, a także efekty w postaci wypracowanych strategii radzenia sobie na studiach, wytwarzane już przez samych studentów. Wszystkie one mogą być oceniane jako niezamierzone rezultaty edukacyjne o charakterze negatywnym, ale też pozytywnym. Ukryte programy oraz ich rezultaty zdają się mieć zindywidualizowany charakter, choć czasami zdają się wykraczać poza obszar jednostkowy, a nawet obszar związany ze studiowaną dyscypliną. Ponadto mają różne poziomy głębokości „ukrycia”. Zaledwie pewna część została uchwycona za pomocą zastosowanej metody, inne nie zostały w pełni ujawnione, m.in. wybrane strategie radzenia sobie na studiach, które prawdopodobnie naruszają prawo. Autorka zauważyła także, że mogą tu oddziaływać na 
wszystkich, zarówno studentów, jak i nauczycieli, jeszcze bardziej ukryte czynniki, np. w postaci polityki oświatowej państwa, przekształceń w modelu uniwersytetu, centralnego definiowania efektów kształcenia (s. 273-276).

Właśnie to stwierdzenie Autorki wiąże się z szerszym rozumieniem ukrytych programów edukacji i - zdaniem piszącego te słowa - powinno być bardziej wyartykułowane w pracy, mimo że dotyka kwestii politycznych i - zapewne - ekonomicznych. Niepokoić może bowiem sama idea powołania systemu bolońskiego, narzucającego scentralizowane rozstrzygnięcia edukacyjne na wielką skalę, swoimi regulacjami obejmującego obecnie około pięćdziesięciu krajów, w tym również krajów pozaeuropejskich. Z jednej strony stwarza on możliwość podkreślenia uniwersalizmu pewnych wartości pedagogicznych, jednak chociażby centralne sterowanie, czy wręcz narzucanie efektów kształcenia wskazuje na realizację ukrytego programu. Jak wiadomo, proces boloński, gdy był inicjowany, miał za zadanie „podciągnąć” edukację europejską do poziomu uczelni amerykańskich, które niekoniecznie realizują ideały wolności czy też wolnej debaty podmiotów edukacji na samodzielnie wyznaczone przez nich tematy. Pragmatyzm amerykański, przebijający się niewyraźnie w obecnym neopragmatyzmie, nie wydaje się opierać na utrwalonych wartościach moralnych, lecz raczej podkreśla ich relatywizm, wygodny dla centrów mających władztwo ekonomiczne. Może zatem w systemie bolońskim chodzić o pomoc w stworzeniu globalnego rynku pracy i przygotowanie „wolnych najmitów” w postaci absolwentów uczelni, ale też samych nauczycieli akademickich. Podkreślane są bowiem nieustannie w jego deklaracjach konferencyjnych te same argumenty-cele, takie jak: mobilność, zatrudnialność, jakość i przydatność (ekonomiczna?) kształcenia, punktowy system oceniania (przypominający Skinnerowskie warunkowanie instrumentalne), weryfikowalność przez zewnętrzne instytucje, tym samym „wysadzając w powietrze” utrwalone dotychczas samorządne wartości instytucji akademickich (por. też: Męczkowska-Christiansen, 2014, s. 19 i n.). Autorka wydaje się świadoma tego procesu, m.in. przedstawiając tabelę 13 ukazującą dualizm między tradycyjnym a aktualnym modelem uniwersytetu (s. 290). Ponadto badania Wiktora Żłobickiego ujawniają, że uczelnie wyższe w swym procesie kształcenia rozwijają zaledwie wybrane cechy osobowości studenta, oddziałując przede wszystkim na jego sferę poznawczą i wzmacniając racjonalny wymiar obrazu własnej osoby, a pomijając czy wybiórczo traktując rozwój emocjonalny, cielesny, społeczny i duchowy (Żłobicki, 2009, s. 253). Właśnie powiązane z tym kompetencje są lekceważone w edukacji uniwersyteckiej i są zagrożone w zorientowanym materialnie, konsumpcyjnie i pragmatycznie świecie. Takie holistyczne rozumienie edukacji, w tym akademickiej, było akcentowane już w latach osiemdziesiątych 
przez krakowskiego pedagoga i filozofa Andrzeja Szyszko-Bohusza. Całościowe potraktowanie edukacji studentów pedagogiki mogłoby zatem sprzyjać redukcji ukrytych programów w ich kształceniu, a tym samym posłużyć do likwidacji ich negatywnych skutków. Dochodzi bowiem do konfliktu w treściach i skutkach kształcenia akademickiego studentów pedagogiki, jak dostrzega Autorka omawianego dzieła, gdy studenci uczą się relacji opartych na zaufaniu, ale też interesowności. Łączenie negatywnych skutków edukacji z jej wymiarem sformalizowanym przez studentów jest też jednopłaszczyznowym postrzeganiem wysiłków wszystkich nauczycieli akademickich, wśród których są przecież i ci, którzy już dawno zrezygnowali z metod podających jako nieefektywnych i odbierających aktywność własną ucznia czy studenta. Z otrzymanych wyników wyłania się obraz studentów pedagogiki jako osób niedojrzałych moralnie, gdy właśnie ta dojrzałość jest podstawą przygotowania do - jak pisze Autorka - profesji społecznej pedagoga (s. 283). Zatem jej badania potwierdzają diagnozy uzyskane we wspomnianych badaniach W. Pasternika. Wśród pozytywnych skutków oddziaływania ukrytych programów edukacji akademickiej badaczka wymieniła: efektywne strategie uczenia się, np. z rówieśnikami, ogładę intelektualną, umiejętność prowadzenia dyskusji, uwzględnianie perspektyw innych osób, deklarowaną potrzebę całożyciowej edukacji (s. 285).

Ostatecznie, ujawniając pokłady ukrytych programów akademickiej edukacji, prowadzi się do jawności motywów sił ją kształtujących, zatem racjonalizacji tego obszaru, oraz umożliwia przewidywanie ich konsekwencji edukacyjnych (co jest wypełnianiem ważnej funkcji prognostycznej nauki), jednak jak zaznacza Autorka:

Nie sposób objąć świadomą kontrolą wszystkich elementów osadzonych w złożonych kontekstach, relacji między nimi, ani ostatecznie wyeliminować negatywnych konsekwencji ukrytych programów (s. 295).

Dzieło zawiera także Bibliografię składającą się z niemal czterystu pozycji (w których uwzględniono również przedmiotową literaturę anglojęzyczną), trzynaście tabel w głównym tekście, a także Aneks ze schematami, rysunkami i tabelami oraz przykładami studenckich esejów. Załączniki te, potraktowane łącznie, podnoszą jakość odbioru książki, czyniąc ją atrakcyjniejszą dla czytelnika.

Oprócz kilku już poczynionych spostrzeżeń o charakterze krytycznym należy jeszcze podzielić się kolejnymi refleksjami dotyczącymi recenzowanego dzieła. Wydaje się, że zakres poruszanych problemów jest na tyle rozległy, że mieści się z trudem w granicach możliwości badawczych jednej osoby, co prawdopodobnie wymusiło pewne uproszenia procedury badawczej. Sama problematyka podjęta 
przez Autorkę leży bez wątpienia w polu zainteresowań pedagogów akademickiego kształcenia, zapewne też innych nauczycieli społecznych i humanistycznych kierunków akademickich oraz wszystkich zainteresowanych poruszaną problematyką, w tym studentów pedagogiki i innych kierunków. Obecność dzieła wśród współczesnej naukowej literatury pedagogicznej jest bardzo pożądana, zwłaszcza że dotyczy kluczowej problematyki dla istnienia i rozwoju dyscypliny naukowej i samego zawodu pedagoga.

Dzięki wielostronnemu wprowadzeniu w zasygnalizowane zagadnienia teoretyczne oraz prezentacji uzyskanych wyników badań empirycznych, a także poczynionych przez Autorkę ich interpretacji praca zachęca do namysłu nad tożsamością pedagogiki jako nauki, jej niektórych nurtów, zwłaszcza powiązanych ze wspieraniem osób usytuowanych podrzędnie w hierarchii społecznej, będących „na dorobku”, oraz rysuje dość wyrazisty obraz kształcenia akademickiego, szczególnie studentów pedagogiki, wręcz prowokując do przeprowadzenia innowacji w tym zakresie, chociażby przez powszechne wprowadzenie aktywizujących metod dydaktycznych. Ponadto zachęca do poczynienia konfrontacji z własnym, czyli pedagoga - nauczyciela akademickiego, ale też studenta pedagogiki, oglądem zjawisk i napotkanych rezultatów jako wyników jawnej i ukrytej działalności kształcącej szkoły wyższej, w tym jej negatywnych skutków. Chodzi tu także o ustosunkowanie się do stosowanych przez studentów strategii radzenia sobie na studiach, również tych negatywnych. Książka zmusza zatem do głębszego namysłu nad wykonywanym zawodem, jak i podjętym (lub nie) kierunkiem kształcenia. Może to wyzwolić twórcze działanie, inicjujące zmiany w przestrzeni nie najlepiej ocenionej rzeczywistości akademickiej oraz wśród tworzących ją podmiotów. Być może przyczyni się również do uwolnienia w jakimś stopniu uczelni bądź wydziałów o profilu humanistyczno-społecznym od pogoni za „wymierną produktywnością" w procesie kształcenia podmiotów edukacji akademickiej, a także od podporządkowania jej głównych celów wyłącznie potrzebom rynku i materialistycznej strony ludzkiego życia.

\section{Bibliografia:}

Babbie, E. (2004). Badania społeczne w praktyce. Warszawa: Wydawnictwo Naukowe PWN.

McLaren, P. (2015). Życie w szkołach. Wprowadzenie do pedagogiki krytycznej, wyd. 6. Wrocław: Wydawnictwo Naukowe Dolnośląskiej Szkoły Wyższej.

Męczkowska-Christiansen, A. (2014). Edukacja dla demokracji jako demokracja w edukacji. Wokół podstawowych pojęć. W: K. Gawlicz, P. Rudnicki, M. Starnawski, T. Tokarz 
(red.), Demokracja i edukacja. Dylematy, diagnozy, doświadczenia. Wrocław: Wydawnictwo Naukowe Dolnośląskiej Szkoły Wyższej.

Pasterniak, W. (2003). O pedagogice wyższych stanów świadomości. Zielona Góra: Wydawnictwo Naukowe PTP, Oddział w Poznaniu.

Pauluk, D. (2005). Modele ról kobiety w podręcznikach do wychowania seksualnego. Kraków: Wydawnictwo Uniwersytetu Jagiellońskiego.

Pauluk, D. (2010). Student na współczesnym uniwersytecie - ideały i codzienność. Kraków: Oficyna Wydawnicza „Impuls”.

Szkudlarek, T. (2004). Pedagogika krytyczna. W: Z. Kwieciński, B. Śliwerski (red.), Pedagogika, t. 1. Warszawa: Wydawnictwo Naukowe PWN.

Szkudlarek, T. (1993). Wiedza i wolność w pedagogice amerykańskiego postmodernizmu. Kraków: Oficyna Wydawnicza „Impuls”.

Żłobicki, W. (2009). Edukacja holistyczna w podejściu Gestalt. O wspieraniu rozwoju osoby, wyd. 2. Kraków: Oficyna Wydawnicza „Impuls”. 